\title{
LABORATE TEST FOR FE LEVELS IN KELAKAI BISCUITS
}

\author{
Febby Siharina ${ }^{1}$, Fitri Yuliana ${ }^{2}$, Agustinus Hermino S. Putra ${ }^{3}$ \\ ${ }^{1,2}$ Midwifery Study Program, Universitas Sari Mulia \\ ${ }^{3}$ English Study Program, Universitas Sari Mulia
}

\section{INFORMASI ARTIKEL:}

\section{Riwayat Artikel:}

Tanggal diterima: September 2020

Tanggal di revisi: September 2020

Tanggal di Publikasi: Oktober 2020

Key Word: Kelakai biscuit, anemia, Fe content

\begin{abstract}
A B S T R A C T
As one of the causes of anemia, iron deficiency must be overcome immediately, one of which is by finding taste-friendly food sources that can be consumed easily by anyone who is prone to anemia. This research was conducted in laboratory to determine the levels of iron in Kelakai biscuits which are assumed to be a source of food to treat anemia in adolescent girls or pregnant women. Qualitative and quantitative test were used to obtain the desired results. Based on the research results, it was found that each Kelakai biscuit contained an Fe level of $245 \mathrm{mg} / \mathrm{g}$, which means that the formulation of the Kelakai biscuit could meet the daily needs of iron when consumed 3-4 chips per day based on the absorption of $\mathrm{Fe}$ in adults. Therefore, to further prove the effectiveness of these biscuits in preventing anemia, studies involving samples, either small or large scale, are highly recommended.
\end{abstract}

\section{INTRODUCTION}

Anemia can happen to anyone, including to pregnant women.[1] Anemia itself is a condition in which a person lacks red blood cells to carry oxygen throughout the body.[2] In general, anemia occurs due to several reasons, one of which is bleeding.[3] An adult woman is said to be anemic if the hemoglobin content in her blood is less than $12.1 \mathrm{~g} / \mathrm{dL}$.[3] However, if anemia occurs in pregnant women, further analysis must be taken into consideration.

During pregnancy, the body needs twice as much iron.[4] Iron is an important component in the formation of hemoglobin, which is a part of red blood cells.[5] The need for iron increases because during pregnancy the required blood volume increases by 30 to 50 percent. This happens because the body needs more blood so it can carry oxygen, not only for the mother, but also for the future baby. However, mothers often do not realize the importance of meeting iron needs during pregnancy. In the United States, anemia in pregnant women due to a lack of iron stores is common.[6] About 15 to 25 percent of pregnant women are anemic. This condition can be overcome, but in certain cases, lack of iron in pregnant women does not only cause anemia. This problem can also result in premature babies or babies born underweight. Anemia in pregnant women can be easily treated by adding a special iron or vitamin supplement during pregnancy.[7] During one hour before and two hours after taking iron supplements, a woman is suggested to avoid milk, cheese, yogurt, eggs, coffee, and tea.[8] Some of these intakes can inhibit iron absorption. Consumption of iron supplements can sometimes worsen nausea. To anticipate this, pregnant women are advised to eat small portions but often. Another option is that pregnant women can take iron supplements right before bed.

In some cases that are quite severe, pregnant women need blood transfusions to treat anemia.[9] Not only taking supplements, but how to prevent anemia in pregnant women can meet the iron needs of at least 30 milligrams per day. Pregnant women can add some ironrich foods, including: Red meat, Broccoli

*Korespondensi: 081349702168 
chicken, kale, lentils, tofu, and tempeh.[10] In addition, pregnant women also need to consume a rich intake of vitamin $\mathrm{C}$. This nutrient is important to help absorb iron. Some high intake of vitamin $\mathrm{C}$ include oranges, strawberries, kiwifruit, tomatoes, and peppers. Given that how to treat anemia in pregnant women depends on the cause, it is important to discuss the solution with a doctor. The reason is, sometimes the causes of anemia in pregnant women can also be certain diseases. Research results by Fahruni, et al. (2018) [11] stated that the kelakai plant can be used as functional food, among others, the root of kelakai contains active compounds that have the potential to act as an aphrodisiac, namely alkaloids an saponin, which from the roots of kelakai can supply high levels of $\mathrm{Fe}$ in the leaves so that it can be beneficial for young women and mothers. pregnancy as an alternative to anemia prevention.

Referring to the problems that occur in South Kalimantan, where there are still many cases of anemia in adolescent women and pregnant women, it is necessary to have an innovation with local wisdom in order to prevent anemia. The local wisdom innovation referred to is a biscuit product to prevent anemia as a solution to prevent anemia, which utilizes raw materials for use, which is a typical plant from South Kalimantan and grows a lot in peatlands or wetlands which are expected to help teenage girls and pregnant women meet their needs. daily iron needs, thereby reducing the incidence of anemia in adolescent women and pregnant women.

\section{METHOD}

Research on Kelakai Biscuits was conducted at the Sari Mulia University Pharmacy Laboratory. This quantitative research was conducted with experiments to determine the levels of $\mathrm{Fe}$ in used biscuits made from
Kelakai plants. The sample used was young Kelakai leaves which were then processed into biscuits and tested in the laboratory using both qualitative and quantitative tests. For the ingredients, the materials used in research are very easy to find around the research location. The list of ingredients and their measurements are shown in Table 1.

\section{Table 1. Kelakai Biscuit Formula to Prevent Anemia}

\begin{tabular}{clc}
\hline No. & \multicolumn{1}{c}{ Ingredients } & Amount \\
\hline 1 & Dry Kelakai crude extract $(\mathrm{g})$ & 500 \\
\hline 2 & Wheat flour (tablespoon) & 16 \\
\hline 3 & Cornstarch (tablespoon) & 2 \\
\hline 4 & Powdered milk (tablespoon) & 1 \\
\hline 5 & Cocoa powder (tablespoon) & 4 \\
\hline 6 & Chocolate Chip (g) & 50 \\
\hline 7 & Fine granulated sugar $(\mathrm{g})$ & 100 \\
\hline 8 & Butter $(\mathrm{g})$ & 200 \\
\hline 9 & Egg & \\
\hline
\end{tabular}

\section{RESULT AND DISCUSSION}

The analysis of $\mathrm{Fe}$ content in one Kelakai biscuit using a UV/Vis spectrophotometer obtained the formulation of Kelakai biscuits through qualitative and quantitative tests. The qualitative test on the filtrate using the KSCN solution showed that the solution turned red, which means that the sample contained positive $\mathrm{Fe}$. Whereas the quantitative test began with the manufacture of the main standard solution of $\mathrm{FeCl} 3$ 100ppm, the solution was then added with $\mathrm{KSCN}$ reagent to form $\mathrm{Fe}(\mathrm{SCN})_{3}$, and then it was made into 5 standard solutions with a concentration of 1ppm, 3 ppm, 5 ppm, 7 ppm, and 9 ppm. The absorbance of all standard solutions that had been prepared was measured using a UV/Vis 
spectrophotometer with an absorption wavelength of $481 \mathrm{~nm}$. In addition, the absorbance of the solution was also measured through the filtrate sample that had been reacted with $\mathrm{KSCN}$. The results were then analyzed using the linear equation for the relationship between concentration and absorbance.

Based on the test, it was found that each Kelakai biscuit contained an Fe level of 245 $\mathrm{mg} / \mathrm{g}$, which means that the formulation of the kelakai biscuit could meet the daily needs of iron in adolescent girls $15 \mathrm{mg}$ to $30 \mathrm{mg}$ per day and daily iron needs for pregnant women as much as $60 \mathrm{mg}$ per day (Table 2). The Fe content in the Kelakai biscuit formulation is almost the same when compared to bloodadded tablet drugs such as Sangobion which contains $250 \mathrm{mg}$ of $\mathrm{Fe}$, and $300 \mathrm{mg}$ of Ferofort.

\section{Table 2. Information on Kelakai Biscuits}

\begin{tabular}{|l|l|l|}
\hline No & Item & Note \\
\hline 1 & $\begin{array}{l}\text { The weight of 1 biscuit } \\
\text { chip }\end{array}$ & $50 \mathrm{mg}$ \\
\hline 2 & Fe content in 1 chip & $245 \mathrm{mg}$ \\
\hline 3 & $\begin{array}{l}\text { The number of biscuits } \\
\text { in one package }\end{array}$ & 4 \\
\hline 4 & $\begin{array}{l}\text { Total Fe content in one } \\
\text { package }\end{array}$ & $980 \mathrm{mg}$ \\
\hline 5 & $\begin{array}{l}\text { Recommended } \\
\text { consumption in a day* }\end{array}$ & $\begin{array}{l}3-4 \\
\text { chips }\end{array}$ \\
\hline $\begin{array}{l}\text { * Recommendations for a day to eat 3-4 biscuits } \\
\text { because iron absorption in adults is only 5\% - } \\
15 \% \text { or around 12.25 to 36.75 mg per biscuit, } \\
\text { while the daily needs of pregnant women is 60 } \\
\text { mg/day and young women is 15-20 mg/day. }\end{array}$ \\
\hline
\end{tabular}

There are some nutrients needed by pregnant women to avoid anemia in pregnancy.[12] Therefore, in this discussion, in addition to iron or $\mathrm{Fe}$, some other substances are worth discussing. To start off, basically folic acid is needed by pregnant women, especially to maintain a healthy body and optimize fetal development in the womb.[13] Folate is a group of B vitamins, whose function is to form healthy red blood cells. Usually, the cause of anemia is due to a lack of B vitamins, and this can also be caused by a lack of folic acid intake. If pregnant women are deficient in folate, what happens is the number of red blood cells will decrease. The worst risk for babies is birth defects.[14] Anemia in pregnant women caused by a deficiency of folic acid can usually result in birth defects that occur in the spine, even in the brain. Babies are also very at risk of being born prematurely.

The second one deals with vitamin B12 deficiency anemia. Anemia in pregnant women can also be caused by a lack of vitamin B12 intake.[15] Where the body really needs vitamin B12 to form red blood cells. As much as possible, pregnant women always meet their intake of vitamin B12 from various food sources. Lack of vitamin B12 intake in the body can cause a decrease in red blood cells. This is what then causes the body to feel tired and lethargic, because red blood cells carry oxygen to all organs of the body.

The third one is iron deficiency anemia. Apart from folic acid, a pregnant woman also needs adequate iron intake.[16] When the body is deficient in iron, what happens is the amount of hemoglobin decreases. One of the causes of anemia in pregnant women is due to iron deficiency. If the hemoglobin in the body is reduced, it will also affect red blood cells. The reason is hemoglobin is a protein that carries oxygen throughout the body and lungs. If a pregnant woman is deficient in iron, there are several risks that will occur if it is not addressed immediately. For example, such as a drastic weight loss after childbirth or the birth of a premature baby may occur, even losing a lot of blood during childbirth, causing depression in pregnant women.[17] 
As analyzed in this research, the anemiapreventing Kelakai biscuits come from the Kelakai plant which has benefits for the prevention of anemia for young women and pregnant women because iron is needed by adolescent women who are menstruating, pregnant, or breastfeeding. This is in line with the results of previous research conducted by Susanti, et al. (2016) which states that Kelakai plants are used for functional food.[18] The success of this Kelakai biscuit product is largely determined by the selection of the Kelakai plant, the processing of Kelakai into dry simplicia, and the processing of Kelakai extracts to be biscuits.

With regard to the results of the analysis, further studies may take into consideration focusing on the consumption of Kelakai biscuits by pregnant women or by adolescent girls with the case of iron deficiency anemia. The small and widespread studies may be needed to see the efficacy of these biscuits to prevent anemia in Indonesia with small or, perhaps, larger samples.

\section{CONCLUSION}

Kelakai plants can be processed into various kinds of food, one of which is biscuits. The proper processing of Kelakai biscuits will help maintain the iron content in each biscuit. With this Kelakai biscuit formulation, it is hoped that it can help the daily iron needs required by young women, pregnant women, and society in general. Therefore, further studies are worth supporting.

\section{REFERENCE}

[1]. Bencaiova, G., Burkhardt, T., \& Breymann, C. (2012). Anemia-prevalence and risk factors in pregnancy. European Journal of Internal Medicine, 23(6), 529-533. doi: 10.1016/j.ejim.2012.04.008
[2] Breymann, C. (2015). Iron Deficiency Anemia in Pregnancy. Seminars in Hematology, 52(4), 339347. doi:10.1053/j.seminhematol.2015.07.003

[3]. Giger, U. (2009). Anemia. Small Animal Critical Care Medicine, 518523. doi:10.1016/b978-1-4160-2591-7.101201

[4] Alibabić, V., Šertović, E., Mujić, I., Živković, J., Blažić, M., \& Zavadlav, S. (2016). The Level of Nutrition Knowledge and Dietary Iron Intake of Bosnian. doi: 10.1016/j.sbspro.2016.02.112

[5]. ORTNER, D. J. (2003). Reticuloendothelial and Hematopoietic Disorders. Identification of Pathological Conditions in Human Skeletal Remains, $\quad 359-382$. doi:10.1016/b978012528628-2/50051-X

[6]. Georgieff, M. K. (2020). Iron Deficiency in Pregnancy. American Journal of Obstetrics and

Gynecology. doi:10.1016/j.ajog.2020.03.006

[7]. Okam, M. M., Koch, T. A., \& Tran, M.-H. (2017). Iron Supplementation, Response in Iron-Deficiency Anemia: Analysis of Five Trials. The American Journal of Medicine, 130(8), 991.e1991.e8. doi:10.1016/j.amjmed.2017.03.045

[8]. Mazanec, E., Romm, A., \& Bove, M. (2010). Pregnancy: Second Trimester. Botanical Medicine for Women's Health, 362369. doi:10.1016/b978-0-443-07277-2.000167

[9]. Giger, U. (2015). Anemia. Small Animal Critical Care Medicine, 575580. doi:10.1016/b978-1-4557-0306-7.001082

[10]. Alibabić, V., Šertović, E., Mujić, I., Živković, J., Blažić, M., \& Zavadlav, S. (2016). The Level of Nutrition Knowledge and Dietary Iron Intake of Bosnian Women. Procedia - Social and Behavioral Sciences, 
217, 1071-1075. doi: 10.1016/j.sbspro.2016.02.112

[11]. Fahruni, F., Handayani, R., \& Novaryatiin, S. (2018). Potensi Tumbuhan Kelakai (Stenochlaena palustris (Burm.F.) Bedd.) asal Kalimantan Tengah sebagai Afrodisiaka. Jurnal Surya Medika (JSM), 3(2), 144-153. Doi:10.33084/jsm.v3i2.114

[12]. Asali, F. F., Tayyem, R. F., Allehdan, S. S., Mahfouz, I. A., \& Bawadi, H. A. (2020). Use of dietary supplements among pregnant women in the center of Jordan. NFS Journal, 20, 4347. doi:10.1016/j.nfs.2020.07.001

[13]. Greenberg, J. A., Bell, S. J., Guan, Y., \& Yu, Y. H. (2011). Folic Acid supplementation and pregnancy: more than just neural tube defect prevention. Reviews in obstetrics \& gynecology, 4(2), 52-59.

[14]. Denise Williams, M., \& Wheby, M. S. (1992). Anemia in pregnancy. Medical Clinics of North America, 76(3), 631647. doi:10.1016/s0025-7125(16)30344-3

[15]. Tulchinsky, T. H., \& Varavikova, E. A. (2014). Nutrition and Food Safety. The New Public Health, 419-469. doi:10.1016/b978-012-415766-8.00008-2

[16]. Lynch, S. R. (2003). ANEMIA (ANAEMIA) | Iron-deficiency Anemia. Encyclopedia of Food Sciences and Nutrition, 215-220. doi:10.1016/b0-12-227055-x/000419

[17]. Dama, M., Van Lieshout, R. J., Mattina, G., \& Steiner, M. (2018). Iron Deficiency and Risk of Maternal Depression in Pregnancy: An Observational Study. Journal of Obstetrics and Gynaecology Canada, 40(6), 698703. doi:10.1016/j.jogc.2017.09.027

[18]. Susanti, Y., Briawan, D., Martianto, D. 2016. Suplementasi Besi Mingguan Meningkatkan Hemoglobin Sama Efektif Dengan Kombinasi Mingguan Dan Harian Pada Remaja Putri. Jurnal Gizi Pangan. 13(1):27-34. 